Portland State University

PDXScholar

\title{
Migrant Remittances, Population Ageing and Intergenerational Family Obligations in Sri Lanka
}

Michele Ruth Gamburd

Portland State University, b5mg@pdx.edu

Follow this and additional works at: https://pdxscholar.library.pdx.edu/anth_fac

Part of the Social and Cultural Anthropology Commons Let us know how access to this document benefits you.

\section{Citation Details}

Gamburd, Michele Ruth, "Migrant Remittances, Population Ageing and Intergenerational Family Obligations in Sri Lanka" (2015). Anthropology Faculty Publications and Presentations. 76.

https://pdxscholar.library.pdx.edu/anth_fac/76 


\title{
MIGRANT REMITTANCES, POPULATION AGEING, AND INTERGENERATIONAL FAMILY OBLIGATIONS IN SRI LANKA
}

Michele Ruth Gamburd

September 2014

Transnational Labour Migration, Remittances and the Changing Family in Asia. Hoang Lan Anh and Brenda Yeoh, editors. Palgrave Macmillan.

\begin{abstract}
As Sri Lanka's population ages, its migrant women face a difficult choice: should they work abroad to remit money to provision their families, or should they stay at home to look after elderly kin? Although numerous studies have explored migration's effects on children, fewer works focus on issues of elder care. This essay presents contextualizing information on transnational migration from Sri Lanka and the rapid ageing that is transforming the country's population structure from a pyramid with many youth and few elders into a column. Using qualitative ethnographic data gathered from a labour-sending village in southern Sri Lanka, this anthropological essay considers social priorities around remittances and intergenerational family obligations for care work. Villagers make decisions about allocating able-bodied family members' labour based on key concepts of filial duty, combined with an analysis of a family's financial and social resources and the vulnerabilities of its members based on their gender and age. Critiquing assumptions about elders' lack of economic activity, the essay notes their key role in facilitating labour migration. The data reveal the importance of gender roles, educational achievements, and generational shifts in evaluating emerging practices. In the future, intergenerational family obligations to mutual care will persist despite population aging. But as extended families shrink and care work grows more demanding, choices between elder care and migrant remittances will become more challenging.
\end{abstract}

KEY WORDS [migration, remittances, extended family, ageing, demographic shift, care work, Sri Lanka]

\section{INTRODUCTION}

In the early decades of the twenty-first century, countries participate increasingly in the global economy. Many developing nations, such as Sri Lanka, send not only goods but also labourers into international markets. Since the late 1970s, working-class Sri Lankans have sojourned in West Asia as guest workers in ever-growing numbers. ${ }^{1}$ In 2009, when the data analysed here were gathered, Sri Lanka had a population of 20 million, and roughly 1.8 million transnational migrants worked abroad (SLBFE, 2010: 4, 142). Migrants thus constituted 9 per cent of the population, and over half of the migrants were women (SLBFE, 2010: 6). 89 per cent of these sojourner women worked as domestic servants, most of them in the Gulf (SLBFE, 2010: 11). Female migrants' most often stated goal is to earn money abroad, buy land and build a house in Sri Lanka, and improve their family’s status. Recently, members of the younger

\footnotetext{
${ }^{1}$ Labour migration is not the only source of transnational mobility for Sri Lankans. Over the past 50 years, a steady trickle of the rural elite has moved to the capital city of Colombo and abroad to Australia and the United States (Morrison, 2004: 32; Waxler-Morrison, 2004: 246). The country has also seen significant outmigration of Tamil-speaking citizens due to the long-standing civil war (e.g., Thiranagama 2014: 268).
} 
generation (often well-educated children of the older labour migrants) are going abroad, heading not only to the Gulf but also to more desirable destinations such as Korea, Cyprus, Malaysia, Israel, and Italy, sometimes with the hope to settle permanently in their host country.

As scholars have repeatedly pointed out in cases worldwide, migration patterns affect family strategies for caring for household members (Cole and Durham, 2005: 12; Kusakabe and Pearson, this volume; Lamb, 2009; Magazine and Sanchez, 2005; McKay, this volume; Parrenas, 2005; Rao, this volume). Although a number of scholars have written about the effects of migration on the children of migrants (Athauda et al., 2000; Gamburd, 2008; Nicholson, 2006; Parrenas, 2002, 2005), fewer have examined migration outcomes for elders (Lamb, 2009; Liu, 2014). Care for elders is an issue of growing global importance, particularly in the face of widespread population ageing now taking place in developing nations.

Sri Lanka's population is aging faster than that of most developing countries (de Silva, 2007: 23). ${ }^{2}$ The population size is stabilizing, but the population structure is changing rapidly, from a pyramid with many young people and few elders, to the column that characterizes most developed nations. The change will have a dramatic outcome; Sri Lanka 'will have the third oldest population in Asia and the largest share of elderly relative to its income status in the world by 2025' (Gamaniratne, 2007: 2-3). The change in the population structure will create significant social, political, and economic challenges in the near future, as fewer children are born, family sizes shrink, elders need increasing amounts of care, and individuals have fewer siblings with whom to share these filial responsibilities. Douglass (2014: 315) refers to this situation as a 'decline of the intergenerational resilience of households' and queries whether (and if so, how) transnational labour migration can help families, households, and societies sustain themselves and cope with demographic change.

As the demographic shift progresses, how will Sri Lankan families navigate the confluence of these trends in migration and demography? In this article, I ask how emerging remittance practices will influence existing family relations, and how changing family structures and care needs will affect migration strategies. Key to investigating these topics is learning how families prioritize the importance of remittances and care work. Currently, the burden of care is shouldered by women of the 'sandwich generation,' the working-age population that looks after both children and elders. Coincidentally, women in this demographic group also make up the bulk of the transnational domestic workers who sojourn in the Gulf, remitting much-needed foreign exchange.

Based on qualitative ethnographic data gathered in 2009, this anthropological essay explores how Sri Lankan families formulate strategies to cope with social reproduction. Drawing on concepts of linked lives (Lloyd-Sherlock and Locke, 2008) and global householding (Douglass, 2014: 313), I focus on intergenerational obligations, examining what happens when migration comes into conflict with gendered kinship duties to care for needy children and elders. Insights from Sri Lanka may shed light on patterns of labour migration and population ageing in the wider global economy.

\section{WORKING-CLASS MIGRATION TO THE GULF: FAMILY AND FINANCES}

\footnotetext{
${ }^{2}$ Median age in Sri Lanka is projected to increase from 30 in 2001, to 33 in 2011, to 43 in 2041 and 47 in 2081 (de Silva, 2007: 23).
} 
Since 1992, I have studied the effects of labour migration on residents in Naeaegama, ${ }^{3}$ a coastal village of Sinhala-speaking Buddhists in Sri Lanka’s Southern Province. In Naeaegama, as in much of the rest of the country, available jobs for working class individuals are mostly poorly paid and temporary (Jayaweera et al., 2002: 24). Employment opportunities for men include work in the armed services or the tourism industry, civil service jobs, daily manual labour jobs, and self-employment as cinnamon peelers or makers and peddlers of coconut fibre brooms. Opportunities for women include making coconut fibre rope, teaching, and working in local garment factories. Most significantly, since the early 1980s a large and ever-growing number of women from Naeaegama have gone to work abroad as domestic servants (Gamburd, 2000). ${ }^{4}$ Although transnational female domestic workers earn only an average of US\$ 100 - 120 a month while abroad, this is more than double the median monthly per capital income for Sri Lanka (a bit less than US\$ 40 in 2006 (Department of Census and Statistics, 2007: 28)). A transnational domestic worker earns between two and five times what Naeaegama women could earn working in Sri Lanka, and such wages equal or exceed the wages earned locally by most village men.

In 2009, about 10 per cent of Naeaegama residents had experience working abroad, and roughly 50 per cent of the village households had or had had at least one person abroad. Threequarters of these migrants were female. Reflecting national trends, most female migrants from Naeaegama came from the 20-45 year age range, had six to nine years of schooling, were married and had two or more children, and had not otherwise worked outside the home (Eelens et al., 1992; Weerakoon, 1998: 102) Data from Naeaegama corroborate studies that suggest that each migrant woman supports an average of four to five members of her family (Jayaweera et al., 2002: 1; Weerakoon, 1998: 109).

Kinship imposes intergenerational rights and moral obligations throughout the extended family (Stone, 2010: 5). Migrants earn wages and send remittances to their families back home to fulfil a number of purposes. Migrants often borrow funds from moneylenders in order to pay manpower recruitment agencies. Thus in their first months of employment, their remittances often repay these debts (Gamburd, 2000). Filial duties create fiscal responsibilities, and remittances repay symbolic debts to families (see also Sobieszczyk, this volume). At the same time, remittances create further obligations within the family. 'Deposited,' in a metaphorical sense, into the domestic economy, remittances count as contributions to a savings account or as payments to an insurance scheme. A migrant who works to reproduce the whole family (including children and elders) at the current time could be seen to repay costs for his or her own childhood upbringing and to save for his or her future retirement. Families most often view these exchanges between generations as a form of generalized reciprocity, in which no accounts are kept (Cronk, 2008) and for which no thanks are expected. Nonetheless, filial obligations and duties create a firm sense of social responsibility between family members, which most individuals strive to the best of their ability to meet. Years of family history create 'webs of interdependence' (Liu, 2014: 305) and 'networks of obligations' (Kusakabe and Pearson, this volume) across generations - duties and expectations that link lives and evolve over the life course.

\footnotetext{
3 'Naeaegama,' or 'the Village of Relatives,' is a pseudonym. Throughout this paper, I also use pseudonyms for interviewees in order to protect their privacy.

${ }^{4}$ From 1988 to 2007, female migrants outnumbered males, but in recent years, greater numbers of men have journeyed abroad (SLBFE, 2012: Overview, Table 1).
} 
In Sri Lanka as elsewhere in the developing world, choices about migration depend not only on individual whims and family conversations, but also on larger social and economic factors (see Hoang and Yeoh, this volume; Yea, this volume). When people cannot make ends meet at home and migrate in order to support their families with remittances, they face challenges in 'doing family' at a distance (Locke, Seeley and Rao, 2013b: 1883). The volume editors point out in the Introduction that need for remittances and subsequent migration can shift not only individual identities and family relations but also social conventions in sending countries. Family negotiations take place within (and simultaneously recraft) an 'intergenerational contract between parents and children’ (Huijsmans, 2014: 299-300). Indeed, demographers use this concept to evoke 'the dependencies between generations' (Whitehead, Hashim and Iversen, 2007:5), considering both cooperation and possible conflicts between family members regarding the exact nature of kin obligations and expectations. In conversation with the current literature on householding, I here explore 'the changing nature of intrahousehold dynamics' while also attending to 'persistence of norms surrounding gender and generational responsibilities and identities’ (Brickell and Yeoh, 2014: 260).

The extended family plays a key role in facilitating women's migration from Naeaegama (Gamburd, 1998), and household financial strategies have changed over the years in light of the multiple demands on migrants' remittances. Evidence suggests that families narrow the bounds of kin-based reciprocity to reward those relatives who directly facilitate the migrant's endeavours (Gamburd, 2004). In many cases, a migrant woman's mother, mother-in-law, or other female relative takes on domestic duties such as child care, thus enabling the migrant to work abroad. The migrant in return finances daily consumption needs for the family and seeks to repay her kin as best she can. How does this debt play out, however, after a migrant's return from overseas? And what happens as individuals in the parental generation age and require care themselves - a situation that may impede a migrant's future mobility and wage-earning capacity? I explore the national context for these family questions below.

\section{DEMOGRAPHIC SHIFT: THE AGEING OF SRI LANKA'S POPULATION}

Most developing countries have a low percentage of elders in the population. Until recently, Sri Lanka shared this characteristic, but the situation is starting to change; in 2000, the percentage of the population over sixty was 9.2 per cent, but by 2050 it is predicted to be 29 per cent (World Bank, 2008: ii, 2). Although the total population in Sri Lanka will remain stable at roughly 21 million people, Sri Lanka’s population structure will change rapidly and dramatically as elders live longer and fertility rates drop.

This population-level transformation, also called a demographic shift or revolution, reflects progress on a number of social indicators. It reflects declines in mortality and increases in longevity due to the development of Sri Lanka's public health system (e.g., the eradication of malaria), as well as inherently gendered changes such as progress in family planning (e.g., greater availability of contraception), the decline in fertility, and the rising rate of female participation in the labour force (de Silva, 2007: 8, 12). On this note, labour migration certainly contributes to lower fertility, because women defer or delay childbearing while they or their husbands are working abroad (Morrison, 2004: 30). Other factors in the shift include a rising standard of living (including better nutrition), changing concepts of the ideal number of children, greater education for women, increased age at marriage, and the availability of social security systems not reliant on kinship networks (Gamaniratne, 2007: 2, 3; World Bank, 2008: 6). 
Although the demographic shift results from a number of positive social changes, it also creates new challenges in caring for the aged. A recent World Bank report suggests that Sri Lanka urgently needs to shore up its traditional support system for the elderly, develop community care services (which are all but non-existent today), figure out income sources for the elderly, adjust the health care system to meet the needs of the aged, and think creatively about how to get older workers back into the labour force (2008: iii-iv). The authors suggest that unless Sri Lanka makes major adjustments to meet this social challenge, it will face 'serious problems or even crisis' (World Bank, 2008: i). The executive summary of the report concludes with boldfaced text: 'Inaction is not a viable alternative' (2008: vi).

In Asia, tradition dictates that relatives take care of elders at home. A 1990 UN study examined the role of the elderly in several developing nations. The vast majority of elders surveyed felt that children should take care of their elderly parents. In Sri Lanka at that time, 85 per cent of elders lived with their children, and often contributed as they could to household tasks such as caring for grandchildren, preparing food, and taking care of other chores (Kaiser and Chawla, 1994: 44-45). A decade and a half later, figures in Sri Lanka had changed little. The World Bank's 2006 Sri Lanka Aging Survey reports that 'nearly 80\% of old people live with their children' (World Bank, 2008: 7), and Gamaniratne reports that 90 per cent of Sri Lankan elders live in multiple-person households (2007: vii). Recent literature on 'householding' challenges ethnographers to consider how migration forces the concept of household to include family members who do not live under the family roof at the moment in question but remain intimately engaged with the people who do.

\section{Elders' economic activity}

The World Bank report notes the need for Sri Lanka to figure out income sources for the elderly and get older workers back into the labour force (2008: iii-iv). These points deserve comment and critique. The evaluation of elders' economic activity must happen on a family or household basis, rather than on an individual basis, in contexts such as South Asia where extended family arrangements are prevalent and the family serves as a unit of economic activity.

As numerous scholars have pointed out (e.g., Kraeger and Schroder-Butterfill, this volume), elders around the world might not engage in wage work, but their domestic labour often enables other family members to work locally or abroad. In Sri Lanka, grandparents regularly look after grandchildren. For example, one Naeaegama grandmother spent twenty years looking after a half-dozen youngsters while her daughter and two daughters-in-law worked abroad. As the demographic shift progresses, people not only live longer but remain active further into old age. The age of sixty, which is a key cut-off point for calculating the dependency ratio, does not necessarily represent a point at which an individual needs or receives care.

A number of elderly informants in Naeaegama made clear that they received much less financial and social support from their families than they provided. For example, a retired military officer (68) noted that even though he had provided lavish dowries for his four daughters when he sent them to their in-laws' homes, all were back home - with their husbands and children - significantly draining the household coffers. 'I have no peace and quiet to sleep, let alone to meditate,' he grumbled acerbically, and lamented the lack of money in his savings account. When grandparents provide food and lodging or enhance a family's economic status by facilitating migration, they perform a financially significant function and should not be considered economically inactive. Such elders are not a burden but rather an asset to the family; 
conversely, as Lloyd-Sherlock and Locke point out (2008:791), it is problem children who can provide 'a prevalent source of unhappiness and vulnerability among older people.'

Despite financial reserves and the ability to work past the age of 60 , the fear of penury in old age is a perennial one. Sri Lankan elders surveyed in 1990 felt that low economic status was their primary problem (Kaiser and Chawla, 1994: 47). Many migrants in Naeaegama went abroad explicitly to address this sort of family predicament. And remittances do aid the extended family; for example, a study in Bangladesh found that migration was beneficial to both the financial status and the health of migrants’ parents (Kuhn, 2005: 204).

Tensions can arise as families strategize about how best to deploy their available resources. Locke and Lloyd-Sherlock note that in developing countries, 'Existing expectations and experiences of life stages are often changing rapidly' (2011: 1132). Pressures on these expectations arise through the conjuncture of the demographic transformation and everincreasing integration into the international labour market in Sri Lanka as elsewhere in Asia (Huijsmans, 2013: 1896). As their parents age, Sri Lankan migrants (particularly women) must choose whether to go abroad and earn money for the family, or remain home and care for their relatives. The remainder of this essay covers normative expectations and practical negotiations in Naeaegama as people struggle to fulfil conflicting kinship duties in light of population ageing and widespread female migration.

\section{FIELD RESEARCH}

In 2009, I undertook two months of systematic research on the topic of intergenerational family obligations surrounding ageing and the life course. My long-time research associate Siri and I realized the difficulty of directly broaching topics of kinship duties and elder care. Such queries probed intimate emotional and financial matters. After nearly two decades of developing rapport with members of these families and learning Naeaegama norms for appropriate interactions, bluntly asking questions about these topics would have seemed inexcusably rude and intrusive. Therefore Siri and I employed an indirect approach. We asked our interviewees to comment on twelve fictional scenarios. ${ }^{5}$ Three scenarios dealing with migrant remittances and intergenerational exchanges of care work are discussed here. We asked that for each scenario, our interviewee discuss what he or she thought the people in the scenario should do, and why they should do it. We asked this of all interviewees. When we felt it was appropriate, we asked whether the interviewee knew of any actual cases of this sort. In some circumstances, people volunteered information about a situation in their own family; in such cases we let people provide as much or as little information as they saw fit. Using this strategy, we garnered rich data without making bad-mannered demands for private information, and our interlocutors could avoid what they perceived as sensitive subjects without discourteously refusing to answer a question.

As a research technique, the use of scenarios offers both advantages and disadvantages. An advantage is that scenarios trigger nuanced replies with lower risks of bias because respondents can be objective in their responses without the fear of having their private lives intruded upon. However, a disadvantage is that this approach is likely to elicit normative

\footnotetext{
${ }^{5}$ The scenario data discussed here come from twenty-nine Naeaegama informants interviewed individually or in groups of two or three during July and August 2009. Some informants (eight) were in their sixties and seventies but did not yet need care. Others needed some extra care (four) or had experience as caregivers for elderly family members (seventeen).
} 
responses - a tendency perhaps enhanced by the presence of my research associate, a high-status local resident. As ethnographers commonly note, what people say they would do in an ideal case can be at odds with what they actually do when confronting a real situation. Therefore here I present some actual cases from Naeaegama as well as villagers' discussions of the scenarios. I contextualize these qualitative ethnographic data within longitudinal information on the village of Naeaegama, its people, its migration patterns, its kinship structures, and its gender norms.

\section{BREADWINNING VS. CARE WORK}

Naeaegama norms and values about remittances and care work unfold in the context of two large-scale trends: increasing transnational migration and rapid population ageing in Sri Lanka. To gather data on this topic, my research associate and I crafted two scenarios to explore family choices between keeping lucrative jobs and caring for needy relatives. In scenario \#1, a husband and wife both have good jobs in Sri Lanka. One member of the couple has an aging mother. When she was able, the mother cared for the couple's children. Now she is ill and needs to receive care herself. We described the fictitious situation and asked our informants, 'How should the ageing mother be cared for, and who should do it?' In scenario \#2, a migrant mother is working abroad. Her mother-in-law, who has been caring for the children, falls ill. We described the situation and asked our informants, 'Should the migrant return?' In both cases, an elder who has facilitated economic activities by providing childcare has reached a state where she must call on her family to reciprocate many years of kin work. Discussions of these scenarios revealed local norms and values surrounding filial duties, social reproduction, social and financial resources, social protection, and the risk of insufficient care for children and elders.

\section{Filial duties}

Informants uniformly agreed that the family members in both scenarios were obligated to care for the ailing relative. In their responses, they frequently used the words 'responsibility' and 'duty.' For example, Janaki (a retired female school principle from a cash-strapped but respected family in the village) remarked about scenario \#1, 'They must look after her. It is a duty, and only rarely would someone refuse to do that job.' People in Naeaegama praised and honoured people who looked after their parents. For example, Lalini and her contractor husband noted that it was better for the family members to take care of the ageing relative themselves than to hire someone. Lalini's husband said, 'We would do it willingly/eagerly for our own relative.' Caring for elderly family members is conceived of normatively as a duty and a pleasure, and fulfilling such an obligation is a source of social prestige in Naeaegama, where neighbours usually know what happens in others' homes.

Turning to an actual example, Lalani and her husband noted that my research associate, Siri, had cared for both his mother and his father. Siri's father had recently passed away in the family home at age ninety-six. Siri had foregone formal employment to look after his father; the family subsisted on Siri's wife's earnings and his father's pension. During our research, many of our other informants remarked positively on the service that Siri and his wife had done for his parents.

Discussing the scenarios, informants often distinguished between acute but short-duration situations (a family member near death, or recovering from a broken leg, or about to undergo a serious operation) and chronic situations requiring long-term care (blindness or dementia). To care for acute illnesses, short-term leaves for the couple in scenario \#1 and (if no one else was available to deal with the problem) a short return from the Gulf by the migrant in scenario \#2 
were advised. For example, Rosalin, an impoverished elderly woman living along, suggested that a migrant should come home if the grandmother were critically sick. Similarly, while peeling cinnamon with her husband, Shiromali said that the wife in scenario \#1 needed to take the ailing elder to the hospital. Shiromali's husband Lalith nuanced the situation, noting that if long-term care was required, the couple should hire someone for a reasonable salary to look after the mother, without quitting their jobs. Informants expressed a consensus that when possible, people in the scenarios should fulfil their filial responsibilities with short-term leaves, without endangering their prospects of long-term employment. These statements reveal that in Naeaegama as elsewhere in the world, people approach 'householding' as a holistic strategy involving the 'translocal production of social security by migrants and their families' (Locke, Seeley, and Rao, 2013b: 1886).

\section{Financial resources}

Informants invariably asked about the financial resources of the families in the fictive scenarios. Reflecting local realities, most informants assumed that the remittances sent by the migrant in scenario \#2 were vital to the family income. Referring to this scenario, retired male school teacher Dayawansa noted, 'She can't leave her job and come home, because the family income would go down. If she didn't need money, she wouldn't have gone abroad in the first place, would she?' Similarly, policeman Anura said, 'If she comes home and she was the one who was supporting her husband and kids, then they'll have economic problems. The husband can look after everything at home if he is good and can control the money that she sends. If the wife comes home, the family will have no income. Everyone depends on her money.' Along these lines, Malani (a middle-aged woman astrologer) remarked, 'If someone here can look after the sick person for pay, it is better for the migrant to stay abroad. If the woman comes home, she can help the person, but there will be no money, so the family will start to have problems.' Amerasinghe (an eighty-five-year-old man recovering from a debilitating stroke) summed it up this way: 'The woman should stay abroad and send money. It would be foolish to come home.' In all of these cases, migrant remittances were deemed key to family wellbeing. The obligation to maintain financial stability for the whole family trumped the migrant's individual duty to provide personal care to the ailing elder.

These sentiments echoed the values used to assess the success and failure of local migration endeavours. For example, Lakmini was a fifty-two-year-old mother of four who had over a dozen years of experience in the Gulf. In 2005, she blamed her daughter's five failed migration attempts for the family's poverty and continued debt. She said, 'My daughter keeps going abroad and coming home after only one year. If she is going to go abroad, she should go and stay there, even if she is suffering.' Lakmini had provided the money for her daughter's endeavours. Breaking a labour contract is detrimental for a migrant; if a domestic servant leaves her job early, she often has to pay for her ticket home out of her savings and then has to pay the recruitment fees for another job. In contrast, women who complete their terms of service successfully can often renew their contracts without charge and receive free round-trip tickets from their employers for a month-long vacation in Sri Lanka. Choices about early return have significant financial effects on entire families, and people usually encourage migrants to complete their contracts.

Informants' discussion of family income in scenario \#1 were slightly more nuanced, given that there were two earner/ care-givers and that they were employed locally rather than in the Gulf. Nevertheless, villagers felt that both members of the couple should if possible retain 
their jobs. Ramani, a stay-at-home mother, noted, 'They need to keep their jobs. These days you need two salaries to live and to take care of a family. So they should get a servant.' Similarly, the elderly man Amerasinghe expressed his opinion: 'They need to keep their jobs, otherwise how will they all eat? If someone quits a job, it's not good for either the old parent or the young couple.' Maintaining a stable income again superseded other familial duties and responsibilities. The actual strategies employed in Amerasinghe's family mirrored those in both scenarios. Amerasinghe's two sons and two daughters had all worked abroad at some point; one daughter sent occasional financial support from Cyprus, and had not returned to Sri Lanka despite her father's stroke. Amerasinghe lived with his son (who at the time of our interview worked as a bus conductor) and his daughter-in-law (who also worked outside the home) and he looked after his three school-age grandsons.

In discussing both scenarios, informants regularly asked whether the ailing relative had property or a pension, and whether the migrant's husband had a job. If the potential caretaker was a major breadwinner in a family with few if any other resources, economic prudence dictated that the breadwinner keep his or her job. With their lives linked together, the long-term well-being of members of the entire family rested upon these financial decisions.

\section{Social networks}

Another major issue pertained to the social resources that the families in the scenarios could call upon. Informants in Naeaegama assumed that extended families would and could provide short- or long-term labour to deal with health crises. Gender played a role in discussions of which member of the couple in scenario \#1 should take leave or give up a job. Janaki suggested that it would be rarer for the husband to give up his job than for the wife to give up hers. This view aligns with the general expectation that women will do care work and men will serve as breadwinners. It also reflects men's ability to earn more than women do on the local job market. Most informants suggested, however, that if other individuals were available to do care work, those people should be called upon, rather than asking either of the spouses in scenario \#1 to give up their jobs or asking the migrant in scenario \#2 to return home.

Family members were preferred as care-givers, but hiring help was also a common suggestion. For example, a returned female migrant Indrani suggested for the couple in scenario \#1, 'They should hire a servant. Or they could get a daughter or daughter-in-law to help, even if she had to give up her job.' Indrani implicitly suggested that someone already engaged in care work for children could relatively easily expand her role to look after the needy elder. A number of people suggested that poor relations could be called on to take on the duty. For example, Sumitha, a retired female school teacher, commented on scenario \#1: 'Let's suppose that one of the couple has an unmarried relative. Perhaps there's a relative on the sick mother's side. Ask her if she can come to look after the mother. It's best if it's a relative. And if there are young kids, you can hire a servant to look after them. The relative can look after the mother and supervise the servant, instruct her how to look after the kids. If there isn't a relative to bring like this, it's not so good. A servant isn't going to do the job right. You need a trustworthy person.' Daughters, daughters-in-law, and poor female relatives, by virtue of their gender and their kinship connections, could be called upon to take on such long-term, potentially onerous family responsibilities.

Local families seeking servants found themselves in competition with wages offered abroad. The issue of hired care prompted Janaki to lament, 'In the old days people had servants to look after the elders. They gave those servants rice and coconuts in exchange. Now everyone 
has gone abroad, or is at work. One can't find servants now!' She noted that ongoing female labour migration to the Gulf had reduced the pool of available poor relatives and hireable help in the village.

A vocal minority of sandwich generation women, all of whom had experience dealing with the long-term care of needy elders, felt that family members should take on responsibility for ailing elders without passing it on to hired help. For example, Darshani (whose mother-in-law suffered from dementia) felt that for long-term care, one of the couple in scenario \#1 would need to leave his or her job. She noted, 'Hiring someone isn't the same; that person won't treat the aged mother like a family member would.' In this case, one of Darshini's sisters-in-law was working abroad and the other had moved out of the village, delegating their mother's care work to Darshini. Darshini, as wife of the youngest son of the family, had assumed the traditional role as parental caregiver in exchange for her nuclear family inheriting the parents' house and property. Darshini had never worked outside the home, though she made breakfast foods for sale at a local shop. Her care work freed her kin to go abroad, but their migration constrained her family structure and her employment options. The village temple's Buddhist monk, Mahanama Thero, said that he understood the economic need to hold a job, but thought that looking after the elder oneself held intrinsic value and generated karmic merit. In these cases, social norms and religious traditions reinforce the ethic of family responsibility for elders.

\section{Vulnerability}

The fictional individuals' stage in the life-cycle and degree of vulnerability to various sorts of harm influenced how informants discussed the decisions faced by the families in the scenarios. Informants often focused on the age, gender, and amount of attention required by the people who needed care. Indeed, providing ‘social protection’ for elders and children, particularly during life-course transitions, may require that families or households 'renegotiate inter-generational care arrangements’ (Locke, Seeley, and Rao, 2013a: 1874).

Interesting differences arose between the care of elders and the care of children. Informants uniformly suggested that it was more important for the migrant in scenario \#2 to come home to care for her children than it was for one of the couple in scenario \#1 to resign from his or her job and care for the elderly mother. At stake here was malleability of character; children were deemed more likely to 'go wrong' or 'go bad' without maternal care. One informant, a single mother with two grown children, thought that a servant could take care of a needy elder. But she noted: 'You can’t hire someone to look after your kids. The kids won’t turn out right if you do that.' Sumitha similarly stated, 'The migrant woman must come back. If she's not there, then the whole family will be ruined. The education of the kids and other such things won't get done.' Lalith and his wife Shiromali (neither of whom had worked abroad) opined that mothers should not go to the Gulf at all; 'Their kids will go bad.' Shivanthi, a female high school teacher, noted 'It's hard to educate kids if their parents are abroad.' The stakes were different in caring for children and elders; an elder might not receive sufficient help from a servant, but his or her character was not subject to corruption. Without proper care for the children, however, the family's future was at risk. 'Lives are lived interdependently,' as Lloyd-Sherlock and Locke point out (2008:792), and familial social relations play out over generations through the lifecourse of multiple family members.

Gender formed an additional vector of choice in understanding vulnerability and harm. For example, informants asked whether the children in scenario \#2 were sons or daughters, and also wondered about their ages. Daughters (particularly those who had reached puberty) were 
deemed at more risk than were sons. From onset of menstruation until day of marriage, a young woman's parents (particularly her mother) are responsible for guarding her reputation and her virginity, thus preserving the young woman's eligibility for marriage. High school teacher Shivanthi and her mother Emaline agreed that girls could 'get spoiled' without their mothers. Emaline noted, 'If one of the migrant's daughters reaches puberty, there's no way the grandmother can keep track of her.' Such sentiments were widely shared in Naeaegama. Indeed, many female migrants planned their two-year contracts to allow them to be home for their daughters' vulnerable teenage years. In an actual case, a Naeaegama migrant found herself unable to return to the Gulf because her eldest daughter had reached puberty and neither grandmother was able or willing to look after the girl. Another woman told me that she ceased migrating after her eldest daughter turned 13. She said, 'It wouldn't have been worth it to have more money if the kids had gone wrong.' In South Asia, where arranged marriage is key to family status and caste relations, people attend to the supervision of unmarried teenage daughters with great care (Gold, 2010: 81; Kapadia, 1993). In Sri Lanka as elsewhere in the world, 'Individual lives are inter-related with the events and transitions experience by close relatives and associates' (Locke and Lloyd-Sherlock, 2011: 1136).

Households respond contextually to external changes and internal dynamics (Huijsmans, 2014: 294). The household arrangement resulting from bringing in a servant was also subjected to gender-related criteria. For example, speaking of scenario \#2, Ramani said, 'The husband can't take care of the sick mother because you need a woman to take care of another woman. And you can't bring a female servant into the house to take care of the sick mother because the husband is there but the wife is not. So the only solution is for the migrant to come home. The husband can take care of the kids but not of the wife's mother.'

The actual situation in another Naeaegama household mirrored the values Ramani expressed. Lal and his mother for many years looked after Lal's brother's four sons and daughter while his sister-in-law Indrani worked abroad and his brother worked in Sri Lanka. Lal's mother's inability to bathe without aid triggered Indrani’s return from abroad. Indrani had no explicit objections to having a servant take care of an elderly family member; indeed, she said during our interview, 'A servant looked after my mother for a number of years.' Although Indrani's remittances could easily have covered wages for a female servant to care for her mother-in-law, the family deemed the arrangement inappropriate because Indrani herself was not in the home with her husband and brother-in-law. Indrani relinquished her job and returned to Sri Lanka. Both in actual and in fictive cases, Naeaegama villagers were keenly aware that improperly channelled sexuality could damage reputations and destroy marriages, particularly when migration separated spouses for many years.

Hiring domestic help could also create situations of unwanted intimacy. Commenting on the servant who had looked after her mother, Indrani said, 'She was a good person, and there were no problems. Sometimes young servants get involved with other people. But you don't want to get an old person to look after another old person, either.' Here Indrani suggested implicitly that youthful servants had more strength and energy, but that they might also cause problems through sexual affairs and unwanted pregnancies. In other words, ideal servants focused on the reproduction of their employers' households, rather than engaging in reproductive functions of their own.

Children and elders need and are entitled to social protection from their kin particularly during periods of transition (Locke, Seeley, and Rao, 2013b: 1881). As these informants' words suggest, vulnerabilities of gender and age nuance the question of whether a worker should give 
up his or her job to care for children or elders. Mahanama Thero, a local Buddhist monk, caused a gale of laugher with this succinct summary of the dangers: 'If the family gets ruined, it's no use having earned a lot of money. When a woman is abroad, her husband sometimes takes another wife, and the kids are running around like baby monkeys.' In discussing these two scenarios and making actual decisions about migration, informants weighed economic gain from income (from local jobs or from overseas remittances) against various duties and risks in evaluating a strategy that will be for the entire family's long-term benefit. In the process, they highlighted expectations of intergenerational care, debts incurred to parents for their past services, and the long-term investments parents made in their own offspring.

\section{GRANDCHILDREN}

The first two scenarios dealt with the choice of sandwich-generation individuals between keeping a lucrative job and caring for a needy family member; the third scenario asked informants to compare at the grandchild generation the relative value of remittances and care work. My associate Siri and I crafted this scenario to decipher how generational distance and phase in the life-course affected kinship obligations to do care work. In this scenario, an elderly grandmother has two grandchildren. One lives close by and provides 'help from the hand.' One lives far away or works abroad and sends money home. We described the fictitious situation and asked informants, 'Which service does the grandmother value more? Why?'

The data gathered from scenario \#3 seem on the surface to contradict the information from scenarios \#1 and \#2. In scenarios \#1 and \#2, informants uniformly felt that family members who had lucrative jobs should not give those jobs up in order to care for elders and children unless no other acceptable care arrangements could be made. This would suggest that remittances and general financial support trump the performance of care service. But evidence from scenario \#3 suggests that from grandchildren, care is valued more than money. As I discuss below, youths' low potential earning power, variation in different generations' affective interactions and financial responsibilities, and an elder's need both for provision and for practical, day-to-day help formed key aspects in informants' evaluation of this scenario.

Naeaegama attitudes toward the fiscal responsibilities of youth may reflect patterns in their employment opportunities. In Sri Lanka, young adults (those up to age twenty-nine) are more often unemployed or underemployed than older adults, with rates in the Southern Province (where Naeaegama is located) higher than those in other areas (Department of Census and Statistics, 2011: 21, 26). Even when work is available, wages for locally employed youth are often quite low. Migrant youth earn more. But in both cases, families hope to use youth earnings for the youth's own future endeavours (e.g., money for a dowry or capital to invest in land or a business). Parents and grandparents prefer not to rely financially on their children, but they welcome and appreciate 'help from the hand,' the 'emotional and instrumental support' (Liu, 2014: 311) that greases the wheels of daily practice.

In migrant families where women from the sandwich generation had worked abroad, a grandparent's investment of devotion, love, and time created reciprocal obligations and duties for grandchildren. A number of informants commented on how much they loved their grandchildren. For example, Perera, a house-painter, suggested that grandchildren and grandparents often had close emotional bonds, especially if the grandparent had cared for the child while the mother worked abroad or outside the home - as his mother-in-law had done during his wife's absence, and as he and his wife did for their daughter. 'Grandchildren often love their grandparents more 
than they love their own parents,' Perera said with a wide smile. 'If your kids' kids are around, it's good. It's busy.'

When asked which grandchild was most valued in scenario \#3, Emaline (a grandmother) replied, 'That one is obvious, isn't it?' She felt the answer was so straightforward that it required no discussion, and only replied explicitly after Siri and I twice pushed her to do so. Like most of our informants, she said that the more valued grandchild was the one living next door who stopped by to help. 'The one living abroad can't come and look in. And if the grandmother is dying, the one next door will help. The money isn't worth as much as coming over to help.' Similarly, a retired handyman said, 'The close one is better. The major work is done close by. The best quality is to be there and to help.' Stroke-affected Amerasinghe, who looked after three grandsons while his son and daughter-in-law were at work, put it bluntly: 'You can get by without money, but you need help.' And when pushed to explain his choice of the close grandchild as more valuable, cinnamon peeler Lalith said, 'The close one does the things you can't do with money. You can't do everything with money.' Darshani elaborated on the fickle nature of money. 'Money disappears!' she grumbled. My research associate Siri replied, 'You have money today. I have your money tomorrow. The next day, it's all gone!' From grandchildren, the presence of a reliable helping hand was deemed more valuable than sporadic remittances.

Informants often elaborated on the sorts of service that the grandchild living next door could provide. Titus, a middle-aged father of three sons, noted that the close-by relative could fetch food from the shop and bring water from the well. An older, unmarried woman with no children suggested, 'Those relatives look in and see about your suffering and health, no?' A poor single mother said, 'You need someone nearby to ask if you have had something to eat and drink, to ask if your eyes are okay.' Another women noted that her own aged mother, for whom she had cared up until her death a month before our interview, had told her, 'You are here to give me a glass of water.' Other interviewees mentioned similar low-cost but vitally important services, including help standing up or drawing water for a bath at the well or for use in the toilet. Ramani said, 'It's better to have kaenda (a low-cost but nutritious vegetable and rice gruel) from the near grandkid than to have fancy foreign food from abroad.' A retired maskmaker noted of scenario \#3, 'Money isn't what's needed in this case. What's needed is someone to look after the grandmother.' He asserted with pride that looking after elders in this way was a Sri Lankan custom.

Although receiving help from the hand of a grandchild was deemed superior in most discussions of scenario \#3, many informants did note the continued importance of money. Sumitha did not rank the service of the two grandchildren. She said, 'Both are good. One sends money and the other looks after the grandmother. Without money, you can't help someone. You must have both.' Similarly, Janaki opined 'One can't live without money! It is nice to look in on someone, but we need money to live. For every step, we need it. Everything is expensive. Medicine is expensive. You need 600 Rupees just to speak two words with the doctor! That's just for five minutes and a prescription!' She went on to detail the expenses incurred in curing a serious infection on her husband's leg, and the need to purchase a cochlear implant for her deaf grandchild. Rosalin, a poor elderly woman who lived alone in a ramshackle house, simply noted that in her opinion, the money would be more important. All three of these informants were older women who could still take care of themselves, but who faced financial difficulties.

The replies above suggest that individuals in the grandchild generation are burdened with fewer financial obligations than are individuals in the sandwich generation, but they are still 
expected to provide care services for a grandparent if they are in the vicinity. My research did not directly explore whether and how a grandchild's obligation changed in scenarios where no other family members were available to provide financial support to the elder, but data overwhelmingly suggest a baseline requirement for money. Also, information from other research scenarios (not discussed in detail in this essay) shows that the obligation to care for an elder is passed along family lines. Grandchildren would be obliged to assume financial responsibilities if their seniors had not already done so. Nevertheless, family obligation thins over the generations, particularly if an elder has no children, has not provided care for nieces, nephews, or other junior relatives in the past, or has few or no valuable assets or independent sources of income (Gamburd, 2013).

An ideal situation for an elder, several interviewees suggested, would be to have family members both at home and abroad. For example, policeman Anura discussed one of his relatives, an older man who lived alone. 'He has a son in a nearby town, a married daughter living across the street, and a married daughter living in Oman. The daughter across the street can give meals and look in on him. The others are sending money. The one who is married to a doctor comes if there are any health problems.' Similarly, Indrani and her son discussed scenario \#3 energetically. Indrani asserted (as many informants did) that the child nearby was more valued. Indrani's son, however, pointed out, 'The far-away one is doing what he can from a distance. Sending money is also good. You need that money to buy medicine and things like that.' He then personalized the question, noting that his brother was sending money from Korea, while he himself was at home to help. All of these informants implicitly reinforce the importance of the extended family in providing both finances and 'help from the hand' for aging relatives.

\section{CONCLUSION: PONDERING THE FUTURE}

The data gathered from these three scenarios suggest that Naeaegama residents highly value both care work and remittances. Family members' duties and obligations vary by gender and generation. Patterns in the data show that the sandwich generation holds primary responsibility to support an elder financially. In that generation, men are expected to earn a living, but if a man cannot support the family, his wife must assume the burden, often by working abroad. This obligation supersedes her duties as care-giver to an elderly parent or inlaw, but may not supersede her obligation to her children, particularly her teenage daughters. Grandchildren's primary responsibilities are to care for their grandparents, unless financial difficulties make earning money a priority.

What implications do these modest findings hold for a discussion of the future of Sri Lankan migration, remittances, and the extended family in a context of rapid population ageing? The World Bank report on ageing in Sri Lanka suggests that modernization in Asia brings about a series of changes that strain traditional family support of elders: 1) lower fertility means that there are fewer children to share care; 2) higher education levels among children may lead to differences of opinions between parents and children (e.g., about who should provide care, and how much); 3) female labour force participation may decrease the number of caregivers at home, and 4) rural-urban migration may remove young people from of the rural areas where most of the elders live (2008: 9). In Sri Lanka at the moment, economic necessity prompts labour migration, and female migrants are drawn from the same population as caregivers. As the data from Naeaegama show, migration affects all four factors listed above in ways that will require creative strategies to harmonize financial opportunities and family obligations. The challenges revolve around issues of gender and intergenerational family obligations. 


\section{Gender}

Local gender norms are crucial to understanding elder care. In Sri Lanka as in much of the rest of the world, women live longer than men and are less likely than men to have access to public sector pensions or non-family sources of income (Gamaniratne, 2007: 52). In India, widows occupy a socially and religiously unfavourable position (Lamb, 2000, 1997: 294). In contrast, Sri Lankans in Naeaegama did not discuss ritual inauspiciousness, but both villagers and scholars note that Sri Lankan women of any age should not live alone (Marecek and Appuhamilage 2011). This limitation will cause a gendered variation in care arrangements, particularly as the proportion of elderly women rises in the population.

In addition to the gendered perceptions of the elderly, gender roles also govern care work. The reciprocal bond between parents and children in Sri Lanka is channelled through women, with daughters-in-law and daughters bearing the major responsibility for caring for their parents and parents-in-law. This same group of women has the corner on care work in the international market. The overseas demand for elder care is likely to continue to grow in the United States, Japan, and the European Union as neoliberal state policies in labour-receiving countries continue to privatize care work, and women in those countries turn to market proxies to fulfil their own filial duties (Chang, 2000; Ehrenreich and Hochschild, 2002; Hondagneu-Sotelo, 2007; Ibarra, 2002; Sassen, 2002). Similarly, demand for domestic servants remains strong in the Gulf; for example, 90 percent of households in Kuwait employed at least one domestic servant in the late 2000s (Ahmad, 2010: 27). Thus choices about remittances and care work take place within preexisting national and international understandings of gender identity, family responsibilities, and state-sponsored social services.

While paying careful attention to existing contexts, it is also important to understand how gender roles can and do change. For example, there are changes now underway in roles for Sri Lankan men, who now do more domestic work than in the past in Naeaegama (Gamburd, 2000, 2008) and in Italy (Näre, 2010). Informants currently note the lack of local female servants in Naeaegama; women who can work abroad are eager to do so. But as the migrant profile shifts in Naeaegama and in Sri Lanka as a whole, more men and fewer women are likely to go to the Gulf, due to family preference and government policy (SLBFE, 2010: 139). Thus the gender composition of the migrant labour force remains in flux. Similarly, the current high value of virginity in teenage daughters could change with the growing emphasis in Sri Lanka on women's education and employment (Hewamanne, 2008; Lynch, 2007). Changes of this nature take place slowly, but culturally constructed gender roles are constantly subject to social transformation (Huijsman, 2014; Ortner, 2006).

\section{Intergenerational Family Obligations}

Contrary to many demographic assumptions about elders' economic activity, people in Naeaegama expect that as they age, they will continue to perform vital services for their extended families. Over the past three decades, elders have taken on care work for their grandchildren to allow migrants to work abroad. This pattern seems likely to continue into the future. Culturally shaped intergenerational kinship obligations require that returned migrants and grandchildren will in turn care for family elders when such care is needed.

Within this context, however, migrants' aspirations provide a source of social change. In Naeaegama, a generation of poor migrant women has invested heavily in education for their children. Successful members of this educated younger generation have moved from Naeaegama 
to the capital city of Colombo or are working abroad in destinations such as Korea, Italy, or Australia that provide opportunities for immigration rather than merely allowing cyclical guestworker employment (Brown, 2011; Näre, 2010; Wanasundera, 2001). As predicted by the World Bank report, these younger individuals are likely to find that their careers, their migration trajectories, and their family duties pull them in conflicting directions. They are not, however, likely to forget their financial obligations to family members, as numerous scholarly discussions of remittance behaviour make clear (Naufal and Termos, 2010; Trager, 2005; see also essays in this volume). The issues will revolve not around the availability of funding to support these elders, but instead around the availability of kin to provide 'help from the hand.'

Naeaegama residents value both financial provision and care work, both 'economic and affective exchanges' (Whitehead, Hashim and Iversen 2007:5) when considering the complex web of intergenerational debts and obligations. Ideally, an extended family can provide both sorts of social support for its members. Currently, families use their kinship network to maximize availability, mobility, and job opportunities. Unemployed relatives or poor servants step in to help women in the sandwich generation fulfil their filial duties. Families distribute responsibilities between able bodied adults so as to retain financial stability while simultaneously providing the care required for children and elders. As the demographic transition progresses, however, extended families will grow smaller, and care work will grow more demanding. Both financial and caring responsibilities will fall increasingly on the young. Reallocation of obligations is likely to cause tension, stress, and conflict as family members work together to meet the challenges posed by an ageing population in a globalizing world. 


\section{REFERENCES CITED}

Ahmad, Attiya (2010) 'Migrant Domestic Workers in Kuwait: The Role of State Institutions,' Viewpoints: Migration and the Gulf. Washington: Middle East Institute. Pp. 27-28.

Athauda, Thamara, D. Fernando, and A. Nikapotha (2000) 'Behavioral Problems among the Preschool Children of Migrant Mothers in Sri Lanka', Journal of the College of Community Physicians of Sri Lanka 5: 14-20.

Blackwood, Evelyn (2005) 'Wedding Bell Blues: Marriage, Missing Men, and Matrifocal Follies,' American Ethnologist 32(1): 3-19.

Brickell, Katherine and Brenda S.A. Yeoh (2014) 'Geographies of Domestic Life:

“Householding” in Transition in East and Southeast Asia,' Geoforum 51: 256-261.

Brown, Bernardo (2011) 'Indifference with Sri Lankan Migrants.’ Ethnology 50(1): 43-58.

Chang, Grace (2000) Disposable Domestics: Immigrant Women Workers in the Global Economy. Cambridge, Mass: South End Press.

Cronk, Lee (2008) 'Reciprocity and the Power of Giving,' in J. Spradley, D. W. McCurdy (eds) Conformity and Conflict: Readings in Cultural Anthropology, $13^{\text {th }}$ edition, pp.157-163. New York: Addison Wesley Longman.

de Silva, W. Indralal (2007) Beyond Twenty Million: Projecting the Population of Sri Lanka 2001-2081. Colombo: Institute of Policy Studies.

Department of Census and Statistics - Sri Lanka (2007) Household Income and Expenditure Survey - 2006/07. Colombo: Department of Census and Statistics.

Department of Census and Statistics - Sri Lanka (2011) Sri Lanka Labour Force Survey: Annual Report - 2010. Colombo: Department of Census and Statistics. Accessed 28 January 2011. http://www.statistics.gov.lk/samplesurvey/LFS_Annual\%20Report_2010.pdf

Douglass, Mike (2014) 'Afterword: Global householding and social reproduction in Asia.' Geoforum 51: 313-316.

Eelens F, T. Mook, and T. Schampers (1992) 'Introduction', in F. Eelens, T. Schampers, and JD Speckmann (eds) Labor Migration to the Middle East: From Sri Lanka to the Gulf, pp. 1-25. London: Kegan Paul International.

Ehrenreich, Barbara and Arlie Russell Hochschild (eds) (2002) Global Woman: Nannies, Maids, and Sex Workers in the New Economy. New York: Metropolitan.

Fazlulhaq, Nadia (2009) ‘Old and abandoned.’ The Sunday Times. 9 August 2009, p. 12. 
Gamaniratne, Nirosha (2007) Population Ageing, Policy Responses and Options to Extend Retirement Coverage: Case Study of Sri Lanka. Colombo: Institute of Policy Studies.

Gamburd, Michele Ruth (1998) ‘Absent Women and Their Extended Families: Sri Lanka’s Migrant Housemaids’, in Carla Risseeuw and Kamala Ganesh (eds) Negotiation and Social Space, A Gendered Analysis of Changing Kin and Security Networks in South Asia and SubSaharan Africa, pp. 276-91. New Delhi: Sage India.

Gamburd, Michele Ruth (2000) The Kitchen Spoon's Handle: Transnationalism and Sri Lanka's Migrant Housemaids. Ithaca: Cornell University Press.

Gamburd, Michele Ruth (2004) 'Money that Burns Like Oil: A Sri Lankan Cultural Logic of Morality and Agency’, Ethnology 43(2): 167-84.

Gamburd, Michele Ruth (2008) 'Milk Teeth and Jet Planes: Kin Relations in Families of Sri Lanka’s Transnational Domestic Servants’, City and Society 20(1): 5-31.

Gamburd, Michele Ruth (2013) 'Care Work and Property Transfers: Intergenerational Family Obligations in Sri Lanka,’ in J. Danely, C. Lynch (eds), Transitions and Transformations: Cultural Perspectives on Aging and the Life Course, pp. 151-67. New York: Berghahn Books.

Gold, Ann Grodzins (2010) 'New Light in the House: Schooling Girls in Rural North India,' in D.P. Mines, S. Lamb (eds) Everyday Life in South Asia, $2^{\text {nd }}$ edition, pp. 80-93. Bloomington: Indiana University Press.Hewamanne, Sandya (2008) Stitching Identities in a Free Trade Zone: Gender and Politics in Sri Lanka. Philadelphia: University of Pennsylvania Press.

Hondagneu-Sotelo, Pierrette (2007) Domestica: Immigrant Workers Cleaning and Caring in the Shadows of Affluence. Berkeley: University of California Press.

Huijsmans, Roy (2013) '”Doing Gendered Age”: Older Migrants and Migrant Daughters Negotiating Care Work in Rural Lao PDR and Thailand,' Third World Quarterly 43(10): 19861910.

Huijsmans, Roy (2014) 'Becoming a Young Migrant or Stayer Seen through the Lens of "Householding”: Households "in Flux" and the Intersection of Relations of Gender and Seniority,’ Geoforum 51: 294-304.

Ibarra, Maria de la Luz (2002) 'Transnational Identity Formation and Mexican Immigrant Women’s Ethics of Elder Care’, Anthropology of Work Review 23(3-4): 16-20.

Institute of Policy Studies (2008) Sri Lanka National Health Accounts 2003-2004. Colombo: Ministry of Healthcare, Nutrition and Uva-Wellassa Development.

Jayaweera, Swarna, Malsiri Dias, and Leelangi Wanasundera (2002) Returnee Migrant Women in Two Locations in Sri Lanka. Colombo: Centre for Women's Research (CENWOR). 
Kaiser, Marvin A. and Sandeep Chawla (1994) 'Caregivers and Care Recipients: The Elderly in Developing Countries’, Ageing International 21(2): 42-9.

Kapadia, Karin (1993) 'Marrying Money: Changing Preference and Practice in Tamil Marriage,' Contributions to Indian Sociology 27(1):25-51.

Kuhn, Randall (2005) 'A Longitudinal Analysis of Health and Mortality in a Migrant-sending Region of Bangladesh’, in Santosh Jatrana, Mika Toyota, and Brenda S. A. Yeoh (eds) Migration and Health in Asia, pp. 177-208. London: Routledge.

Lamb, Sarah (1997) 'The Making and Unmaking of Persons: Notes on Aging and Gender in North India’, Ethnos 25(3): 279-302.

Lamb, Sarah (2000) White Saris and Sweet Mangoes: Aging, Gender, and Body in North India. Berkeley: University of California Press.

Lamb, Sarah (2009) Aging and the Indian Diaspora: Cosmopolitan Families in India and Abroad. Bloomington: Indiana University Press.

Liu, Jieyu (2014) ‘Ageing, Migration, and Familial Dupport in Rural China,' Geoforum 51 (305312).

Lloyd-Sherlock, Peter and Catherine Locke (2008) 'Vulnerable Relations: Life-Course, Wellbeing, and Social Exclusion in Buenos Aires, Argentina,' Ageing and Society 28(6): 779803.

Locke, Catherine, Janet Seeley, and Nitya Rao (2013a) 'Migration, Reconfigurations of Family Relations, and Cocial (In)Security: An Introduction,’ Third World Quarterly 34(10): 1872-1880.

Locke, Catherine, Janet Seeley, and Nitya Rao (2013b) 'Migration and Social Reproduction at Critical Junctures in Family Life Course,’ Third World Quarterly 34(10): 1881-1895.

Locke, Catherine and Peter Lloyd-Sherlock (2011) 'Qualitative Life Course Methodologies: Critical Reflections from Development Studies,’ Development and Change 42(5): 1131-1152.

Marecek, Jeanne and Udeni Appuhamilage (2011) 'Present but unnamed: Feminisms and psychologies in Sri Lanka,' in A. Rutherford, R. Capdevila, V. Undurti, I. Palmary (eds) Handbook of International Perspectives on Feminism, pp. 315-334. New York: Springer.

Morrison, Barrie M. (2004) 'Overwhelming Change and Faltering Institutions, 1948-2002', in S.H. Hasbullah and Barrie M. Morrison (eds) Sri Lankan Society in an Era of Globalization: Struggling to Create a New Social Order, pp. 25-56. New Delhi: Sage Publications.

Näre, Lena (2010) 'Sri Lankan Men Working as Cleaners and Carers: Negotiating Masculinity in Naples. Men and Masculinities 13: 65-86. 
Naufal, George and Ali Termos (2010) 'Remittances from the GCC Countries: A Brief Outlook', in Migration and the Gulf (February 2010), pp. 37-41.

http://www.mei.edu/Portals/0/Publications/Migration\%20Gulf.pdf. (accessed 10 October 2010)

Nicholson, Melanie (2006) 'Without their children: Rethinking motherhood among transnational migrant women’, Social Text 24(3): 13-33.

Ortner, Sherry B. (2006) Anthropology and Social Theory: Culture, Power, and the Acting Subject. Durham: Duke University Press.

Parrenas, Rhacel Salazar (2002) 'The Care Crisis in the Philippines: Children and Transnational Families in the New Global Economy', in Barbara Ehrenreich and Arlie Russell Hochschild (eds) Global Woman: Nannies, Maids, and Sex Workers in the New Economy, pp. 39-54. New York: Metropolitan.

Parrenas, Rhacel Salazar (2005) Children of Global Migration: Transnational Families and Gendered Woes. Stanford, CA: Stanford University Press.

Ruwanpura, Kanchana N. (2000) Structural Adjustment, Gender and Employment: The Sri Lankan Experience. Geneva: ILO.

Sassen, Saskia (2002) 'Global Cities and Survival Circuits', in Barbara Ehrenreich and Arlie Russell Hochschild (eds) Global Woman: Nannies, Maids, and Sex Workers in the New Economy, pp. 254-74. New York: Metropolitan Books.

Sri Lankan Bureau of Foreign Employment (SLBFE) (2010) Annual Statistical Report of Foreign Employment 2009. Battaramula, Sri Lanka: SLBFE.

Sri Lankan Bureau of Foreign Employment (SLBFE) (2012) Annual Statistical Report of Foreign Employment 2009. Battaramula, Sri Lanka: SLBFE.

http://www.slbfe.lk/article.php?article=106, accessed September 22, 2014.

Stack, Carol B. (1970) All Our Kin: Strategies for Survival in a Black Community. New York: Harper and Row.

Stone, Linda (2010) Kinship and Gender: An Introduction. $4^{\text {th }}$ Edition. Boulder, Colorado: Westview Press.

Thiranagama, Sharika (2014) 'Making Tigers from Tamils: Long-Distance Nationalism and Sri Lankan Tamils in Toronto. American Anthropologist 116: 265-78.

Trager, Lillian (ed) (2005) Migration and Economy: Global and Local Dynamics. Oxford: AltaMira Press.

Wanasundera, Leelangi (2001) Migrant Women Domestic Workers: Cyprus, Greece and Italy. Colombo, Sri Lanka: CENWOR 
Waxler-Morrison, Nancy (2004) 'Who Will Care for Those Left at Home? The Effect of New Opportunities for Work on Families in Sri Lanka', in S.H. Hasbullah and Barrie M. Morrison (eds) Sri Lankan Society in an Era of Globalization: Struggling to Create a New Social Order, pp. 241-53. New Delhi: Sage Publications.

Weerakoon, Nedra (1998) 'Sri Lanka: A Caste Study of International Female Labour Migration', in S. Sta. Maria Amparita, J. J. Balisnono, R. Plaetevoet, and R. Selwyn (eds) Legal Protection for Asian Women Migrant Workers: Strategies for Action, pp. 97-118. Makati City, Philippines: Ateneo Human Rights Center.

Weismantel, Mary (1995) 'Making Kin: Kinship Theory and Zumbagua Adoptions', American Ethnologist 22(4): 685-704.

Whitehead, Ann, Iman M. Hashim and Vegard Iversen (2007) 'Child Migration, Child Agency and Inter-generational Relations in Africa and South Asia,' Sussex Centre for Migration Research, Working Paper T24. http://www.migrationdrc.org/publications/working_papers/WPT24.pdf, accessed September 22, 2014.

Wilson, Gail (2001) 'Globalisation and Support in Old Age’, Education and Ageing 16(20): 12134.

World Bank (2008) 'Sri Lanka: Addressing the Needs of an Aging Population.' Report No. 43396-LK. Human Development Unit, South Asia Region. http://go.worldbank.org/I14DRI6CS0 (posted 28 May 2008, accessed 15 November 2008). 